\author{
THE EFFECT OF HOSPITALS REGULATIONS ON LOCAL \\ BUSINESS ACTORS IN THE DEVELOPMENT OF THE \\ YOGYAKARTA TOURISM INDUSTRY \\ CASE STUDY: ASTON INTERNATIONAL GROUP \\ Alfian Eikman ${ }^{1}$ \\ Muhammad Muharam Lubis ${ }^{2}$ \\ Baiq Reinelda Tri Yunarni ${ }^{3}$ \\ Fakultas Ilmu Sosial Dan Ilmu Politik \\ Universitas Muhammadiyah Mataram \\ alfian.eikman@ummat.ac.id ${ }^{1}$ \\ muharram.lubis@gmail.com ${ }^{2}$ \\ reineldayunarni@ummat.ac.id
}

\begin{abstract}
This research is trying to explain the effect of selected regulation which enforced by local authorities to protect local business actors from ongoing global competition in hospitality and tourism chain industry while also attempt to grab the benefit of Foreign Direct Investment (FDI) in hotel chain industry to enhance the capabilities of local business comunities. The method that was used in this research is qualitative which construct an overview of how the regulation of Indonesian and local government affect the Aston International hotel chain group whose operate in Yogyakarta. Data in this research collected by interview and desk study processes which found that the selected regulation are succed to balance the need for protecting local business actors while at the same time attracting FDI that bring substantial multiplier effect to the local hospitality and tourism industries. Nevertheless, researcher also discover that there are certain policy contradiction between the central government and local authorities, caused by the lack of coordination within the bureaucracies. Government should take this problem seriously considering that hospitality and tourism industry in Indonesia especially Yogyakarta is an extremely potential factor to boost local economic development.
\end{abstract}

Keywords: regulation, business actor, hotel chain industry, tourism industry.

\title{
PENGARUH REGULASI PERHOTELAN TERHADAP PELAKU BISNIS LOKAL DALAM PENGEMBANGAN INDUSTRI PARIWISATA YOGYAKARTA STUDI KASUS: GRUP ASTON INTERNASIONAL
}

\begin{abstract}
ABSTRAK
Penelitian ini berusaha untuk menjelaskan pengaruh kebijakan yang dilakukan secara selektif yang diterapkan oleh pemerintah daerah untuk melindung pelaku bisnis lokal dari persaingan atau kompetisi global dalam bisnis industri perhotelan dan pariwisata, dengan secara bersamaan berusaha mendapatkan manfaat dari Penanaman Modal Asing (PMA) dalam rantai industri perhotelan untuk meningkatkan kapabilitas komunitas bisnis lokal. Metode yang digunakan di dalam penelitian ini adalah kualitatif yang berusaha menggambarkan bagaimana regulasi pemerintah pusat Indonesia dan pemerintah daerah setempat mempengaruhi rantai hotel Aston Internasional yang beroperasi di Yogyakarta. Data
\end{abstract}


penelitian ini dikumpulkan melalui proses interview dan studi pustaka yang menemukan bahwa regulasi selektif berhasil menyediakan proteksi kepada pelaku bisnis lokal dan secara bersamaan menarik minat investasi atau PMA yang dapat membawa efek domino yang positif terhadap industri perhotelan dan pariwisata lokal. Namun, peneliti juga menemukan beberapa kontradiksi kebijakan antara pemerintah pusat dengan daerah yang disebabkan oleh kurangnya koordinasi di dalam birokrasi. Pemerintah harus memandang serius permasalahan ini, mengingat industri perhotelan dan pariwisata di Indonesia khususnya Yogyakarta merupakan faktor yang sangat penting atau potensial dalam meningkatkan keberhasilan pembangunan ekonomi lokal.

Kata kunci: regulasi, pelaku usaha/bisnis, rantai industri hotel, industri pariwisata.

\section{A. Latar Belakang}

Pariwisata telah menjadi salah satu industri di dunia dan merupakan andalan utama dalam menghasilkan devisa di berbagai negara. Data Badan Pusat Statistik (BPS) menunjukkan penerimaan devisa nasional 2011, wisatawan mancanegera (wisman) memberi kontribusi sebesar Rp 80 triliun dengan total pergerakan wisman sejumlah mencapai 7,6 juta orang. Sementara kunjungan wisatawan dalam negeri menyumbang Rp 123 triliun. Ranking devisa yang diperoleh dari sektor pariwisata bahkan meningkat sejak 20062010. Pada tahun 2009, pariwisata penyumbang devisa terbesar ketiga setelah minyak bumi \& gas serta minyak kelapa sawit dengan total nilai mencapai $\mathrm{Rp}$ 62 triliun.

Keberhasilan pembangunan kepariwisataan Indonesia ditentukan oleh paling tidak tiga pilar utama yaitu keberhasilan dalam pengembangan produk, keberhasilan dalam pemasaran, dan keberhasilan menciptakan sumber daya manusia termasuk masyarakat pariwisata (Fadmawati, 2011). Kebijakan ini telah mampu meningkatkan kunjungan wisatawan dan penerimaan devisa bagi Indonesia. Kemitraan dengan masyarakat lokal disekitar objek wisata turut serta meningkatkan pendapatan sehingga pariwisata merupakan salah satu faktor pemasukan perekonomian Indonesia.

Yogyakarta merupakan salah satu destinasi pariwisata di Indonesia yang banyak dikunjungi oleh para wisatawan baik lokal maupun mancanegara. Potensi yang mampu memikat para wisatawan daerah ini seperti keindahan alam, keunikan budaya serta kehidupan sosial masyarakatnya. Potensi ini menjadi industri salah satu tulang punggung pembangunan perekonomian Kota Yogyakarta dan menjadi andalan dalam mengisi Pendapatan Asli Daerah (PAD). Realisasi pajak hotel-restoran tahun 2011 memberi sumbangan Rp 44,3 miliar. Tingginya angka wisatawan yang datang ke provinsi ini menarik banyak investor baik lokal maupun asing untuk menginvestasikan dananya dalam industri pariwisata di Yogyakarta.

Perhotelan merupakan salah satu industri jasa yang berperan penting dalam keberhasilan dunia pariwisata di Yogyakarta. Seiring meningkatnya perekonomian Indonesia, bisnis pariwisata membawa perkembangan di Yogyakarta. Para investor berjaringan internasional mulai tertarik untuk membangun properti khususnya hotel di Kota Yogyakarta. Tumbuh kembangnya pelaku usaha hotel berjaringan di Kota Yogyakarta memberikan 
nilai tambah (added value) yang signifikan terhadap peningkatan pendapatan penduduk Kota Yogyakarta.

Globalisasi yang berpengaruh terhadap dunia pariwisata menarik sikap peduli pihak manajemen industri pariwisata termasuk juga hotel untuk mengembangkan sistem manajemen dalam mengatur industrinya. Situasi internasional ini secara tidak langsung akan berpengaruh terhadap keberhasilan pengelolaan hotel dari segi kunjungan wisatawan yang datang ke daerah tempat hotel itu berada. Pengelolaan dan pengorganisasian hotel diperlukan tenaga-tenaga profesional sebagaimana kebutuhan industri pariwisata.

Dalam implementasinya, pemerintah lalu mengeluarkan kebijakan lewat Keputusan Menteri Pariwisata Pos dan Telekomonikasi No: KM.112/PW.102/MPPT.96 tentang Usaha Jasa Manajemen Hotel Jaringan Internasional. Terdapat dua hal penting yang menjadi pertimbangan dalam keputusan tersebut pemerintah tersebut. Pertama, bahwa jasa manajemen hotel jaringan internasional memiliki peranan dalam pengembangan dan peningkatan usaha jasa akomodasi sebagai bagian dari industri pariwisata. Kedua, manajemen jaringan internasional yang beroperasi di Indonesia harus berkomitmen untuk menciptakan sinergi berusaha dan menjamin kelangsungan pengembangan usaha dengan melakukan pengalihan dan penguasaan teknologi secara substansial kepada SDM Indonesia.

Dengan munculnya peraturan baru daftar bidang usaha tertutup dan bidang usaha yang terbuka dengan persyaratan di bidang penanaman modal yakni PP No 36 tahun 2010 turut mempengaruhi sektor industri pariwisata. Produk hukum yang merupakan turunan dari UU No 25 tahun 2007 tentang penanaman modal ini menetapkan beberapa daftar usaha tertutup yang dilarang dan terbuka dengan persyaratan sebagai kegiatan penanaman modal. Peraturan ini mensyaratkan beberapa hal tentang pembatasan usaha yang dapat dilakukan oleh pihak asing. Salah satu daftar usaha terbuka dengan persyaratan yakni dalam penyelenggaraan akomodasi seperti hotel berbintang satu, dua, homestay. Hotel bintang satu dan bintang dua dikenai syarat maksimal dana pihak asing sebesar $51 \%$ serta tidak bertentangan dengan peraturan daerah (Perda). Sementara untuk homestay, hanya diperbolehkan untuk pencadangan usaha mikro, kecil, menengah dan koperasi.

Aston International merupakan salah satu grup hotel yang berjaringan internasional di Kota Yogyakarta. Hotel chain ini telah ini memiliki 32 hotel yang tersebar di Indonesia dengan nama brand Aston dengan level bintang empat serta lebih dari 50 hotel dengan Fave pada level bintang dua dan serta 20 proyek hotel baru yang akan dilaksanakan tahun 2012 ini dengan brand Hotel Neo (Nursyifani, 2012). Di Kota Yogyakarta sendiri, hotel ini beroperasi pada segmentasi kelas atas dan menengah. Yogyakarta menjadi salah satu kota diantara dua kota grup hotel ini membangun hotel bintang lima di Indonesia. Dua daearah tersebut yakni Grand Aston City Hall di Medan serta Grand Aston Yogyakarta di Yogyakarta.

Untuk segmentasi kelas hotel budget, grup Aston International mendirikan Fave Hotel yang kini bersaing merebut pangsa pasar hotel bintang 
dua yang telah ada terlebih dahulu di Kota Yogyakarta. Segera akan dibangun juga hotel Neo dikelas yang sama namun dengan konsep yang berbeda dengan Fave Hotel. Untuk segmentasi hotel bintang tiga, grup Aston International juga mendirikan Quest Hotel Mangkubumi.

Kemunculan PP 36/2010 tentang daftar tertutup untuk usaha penanaman modal dapat dikatakan sebagai suatu ancang-ancang untuk menghadapi era globalisasi yang ditandai dengan perdagangan bebas. Khususnya dalam bidang perhotelan, industri ini merupakan bagian dari terpenting dalam industri pariwisata. Peraturan tersebut memberikan ruang kepada unit usaha kecil dan menengah berpartisipasi dalam penanaman modal di industri pariwisata. Pemerintah daerah (Pemda) juga mendapat peranan dalam regulasi menata hotel berkelas satu dan kelas dua serta homestay. Pemda juga harus memastikan bahwa modal asing tidak melebihi kuota syarat yang telah ditetapkan.

Peraturan penanaman modal tersebut ditempatkan sebagai upaya pemerintah untuk meningkatkan pertumbuhan ekonomi nasional, serta hakekatnya mewujudkan kesejahteraan masyarakat dalam suatu sistem perekonomian yang berdaya saing. Sementara pihak hotel juga harus mampu bersaing dalam menghadapi perdagangan bebas dengan memanfaatkan manajemen hotel chains dalam pengembangan industri pariwisata. Manajemen hotel chain dalam mengelola hotelnya harus menyiapkan sistem manajemen yang sempurna untuk menang dalam persaingan di dunia perhotelan dan mencapai tujuan dari hotel tersebut.

Serbuan hotel budget oleh operator berjaringan internasional ini bisa menjadi ancaman bagi hotel-hotel bintang 2 lokal. Hotel budget baru dengan menggandeng manajemen hotel chain tampil dengan desain kontemporer, fasilitas modern, memiliki kamar lebih banyak namun dengan harga yang bersaing. Untuk dapat tetap mempertahankan tamunya pengelola hotel lokal ini mau tidak mau harus segera berbenah diri. Seraya berbenah pemerintah telah mengawal ancaman tersebut dengan beberapa aturan regulasi terkait manajemen hotel berjaringan internasional.

Berdasarkan latar belakang tersebut, maka penelitian ini ingin mengindentifikasi formulasi kerangka kebijakan dan hukum yang dilakukan pemerintah daerah Kota Yogyakarta terhadap pemilik atau pengelola hotel berjaringan internasional segmentasi kelas satu, kelas dua ataupun homestay. Dalam kajian ini, studi kasus akan diarahkan pada grup Aston International yang telah membangun hotel budgetnya di Kota Yogyakarta.

\section{B. Metode Penelitian}

Pembahasan pada penelitian ini menggunakan metode kualitatif dengan menggambarkan atau memaparkan bagaimana kebijakan pemerintah Indonesia dan pemerintah daerah Kota Yogyakarta terhadap industri pariwisata khususnya pada hotel berjaringan internasional dengan mengangkat Aston International di Kota Yogyakarta sebagai studi kasus dalam pembahasan. 
Untuk pembahasan lebih lanjut serta menjawab pertanyaan pada rumusan masalah, peneliti menggunakan data sekunder yang diperoleh dari berbagai literatur baik elektronik maupun tinjauan pustaka. Selain itu, berbagai dokumen resmi pemerintah yang diperoleh langsung dan yang diperoleh melalui sumber elektronik diharapkan dapat mendukung penelitian ini. Untuk memperdalam penelitian ini, juga menggunakan data primer berupa wawancara langsung dengan pihak Aston International di Kota Yogyakarta, Dinas Pariwisata D.I Yogyakarta dan Kota Yogyakarta, dan Badan Penanaman Modal Daerah Istimewa Yogyakarta.

\section{Analisis dan Pembahasan}

\section{A. Kebijakan Pemerintah}

Kebijakan pemerintah dalam industri pariwisata dalam negeri sudah tentu bertujuan untuk mengembangkan industri pariwisata itu sendiri. Namun, terdapat hal-hal yang perlu diperhatikan oleh pemerintah dalam mengambil suatu kebijakan khususnya yang terkait dengan persaingan industri pariwisata global. Salah satu faktor yang harus jadi pertimbangan adalah perjanjian internasional yang telah disepakati oleh pemerintah terkait dengan liberaliasi perdagangan jasa (termasuk perhotelan) di dalam WTO yang diatur melalui General Agreement on Trade in Service (GATS). Kesepakatan yang telah disetujui dalam GATS akan menjadi acuan bagi pemerintah dalam menetapkan kebijakan berupa undang-undang maupun peraturan pemerintah. Kemudian faktor lainnya yang harus diperhatikan oleh pemerintah adalah kebutuhan para pelaku usaha dalam negeri, khususnya terkait dengan perlindungan dalam menghadapi persaingan dengan kompetitor dari luar. Perhatian pemerintah dibutuhkan agar pelaku usaha dalam negeri dapat bertahan dalam menjalankan usahanya dan menghadapi persaingan global di bidang jasa pariwisata yaitu perhotelan. Dari kedua hal yang mesti dapat perhatian tersebut, maka kebijakan yang diambil oleh pemerintah harus dapat mengakomodasi keduanya. Selain dapat menaati perjanjian kerjasama internasional yang sudah ada, pemerintah juga harus mampu melindungi pengusaha lokal yaitu dengan menerapkan kebijakan yang berimplikasi positif terhadap keberlangsungan industri pariwisata dalam negeri.

Untuk memahami implikasi dari kebijakan yang diterapkan oleh pemerintah terhadap pelaku usaha dan berjalannya industri pariwisata khususnya bidang perhotelan, penting untuk memahami terlebih dahulu bagaimana industri pariwisata tersebut dijalankan. Industri pariwisata khususnya bidang perhotelan di Yogyakarta dijalankan sepenuhnya oleh pihak swasta dengan regulasi yang ditentukan oleh pemerintah daerah yang mengacu kepada peraturan pusat. Regulasi ini diatur dalam Peraturan Daerah No.4 Tahun 2010. Pihak swasta yang ingin melakukan usaha dalam bidang perhotelan diharuskan untuk melayangkan izin untuk mendirikan sarana pariwisata kepada dinas perizinan daerah kota Yogyakarta. Setelah mendapatkan izin, pihak yang bersangkutan baru boleh mendirikan sebuah sarana pariwisata berupa penginapan atau hotel. Setelah sarana pariwisata 
berupa penginapan atau hotel berdiri, dinas pariwisata kota bekerjasama dengan dinas-dinasi terkait akan melakukan inspeksi terhadap sarana dan prasarana menyangkut fasilitas, pelayanan, keamanan, kebersihan, dan kesehatan yang akan dijadikan acuan dalam menentukan golongan kelas sarana pariwisata tersebut. Hasil inspeksi ini kemudian akan diajukan kepada asosiasi Perhimpunan Hotel dan Restoran Indonesia (PHRI) Yogyakarta, yang akan menentukan klasifikasi sarana pariwisata berupa penginapan atau hotel sesuai dengan usulan dari dinas pariwisata tersebut.

Kemudian hal berikutnya yang perlu diketahui dalam memahami bagaimana implikasi kebijakan pemerintah terhadap industri pariwisata berupa jasa penginapan dan perhotelan adalah terkait dengan komposisi kepemilikan usaha penginapan dan perhotelan di kota Yogyakarta. Menurut data yang kami peroleh dari asosiasi Perhimpunan Hotel dan Restoran Indonesia (PHRI) daerah Yogyakarta, komposisi kepemilikan penginapan dan hotel di daerah Yogyakarta, seluruhnya dimiliki oleh investor lokal atau dalam negeri baik terkait dengan properti maupun sahamnya. Komposisi ini diasumsikan dipengaruhi oleh regulasi pemerintah yang tertuang dalam PP No 36 tahun 2010 yang menekankan penanaman modal terhadap hotel budget hanya dapat dimiliki oleh pihak asing maksimal $51 \%$. Dengan adanya peraturan pemerintah tersebut, kepemilikan hotel di Indonesia sebagian besar dimiliki oleh investor yang berasal dari dalam negeri.

Penggunaan jasa pengelola manajemen hotel menurut regulasi kepariwisataan yang berlaku di Indonesia diatur melalui regulasi mengenai pelaksanaan usaha manajemen hotel internasional yang dimaksud dalam Keputusan Direktorat Jenderal (Dirjen) Pariwisata No:Kep.06/VI/97. Dalam keputudan Dirjen tersebut diatur mengenai sistem hubungan kerjasama atau pengelolaan dalam bentuk jasa konsultasi, jasa waralaba (franchise), dan jasa pengelolaan. Aturan lainnya terkait kerjasama pariwisata mengenai perhotelan dalam Keputusan Dirjen Pariwisata tersebut antara lain; Pertama, setiap usaha jasa manajemen hotel berjaringan internasional yang beroperasi di Indonesia, agar bermitra usaha dengan pengusaha Indonesia. Kedua, usaha jasa manajemen hotel berjaringan internasional harus berbentuk badan hukum Indonesia sesuai dengan aturan yang berlaku. Ketiga, usaha jasa manajemen hotel berjaringan internasional yang beroperasi di Indonesia harus mendapat izin terlebih dahulu dari Dirjen Pariwisata. Keempat, usaha jasa manajemen hotel jaringan internasional berkewajiban meningkatkan kualitas dan percepatan Indonesianisasi SDM.

Regulasi yang diterapkan oleh pemerintah pusat dan daerah melalui PP No 36 tahun 2010, Keputusan Direktorat Jenderal (Dirjen) Pariwisata No:Kep.06/VI/97, dan Peraturan Daerah No.4 Tahun 2010, kemudian mempengaruhi bagaimana peta industri pariwisata, khususnya pada sektor jasa akomodasi penginapan atau perhotelan di kota Yogyakarta. Dengan dibatasinya jumlah kepemilikan pihak asing dan kebijakan pengelolaan manajemen hotel, menjelaskan bagaimana penginapan atau hotel di kota Yogyakarta kepemilikannya dimiliki oleh investor lokal dan sebagian dikelola oleh operator jaringan hotel internasional seperti, Accor Group, Ibis Group, 
dan Aston Internasional. Dari data yang kami peroleh dari asosiasi Perhimpunan Hotel dan Restoran Indonesia (PHRI) daerah Yogyakarta, dari seluruh hotel berbintang yang ada di wilayahnya, sepuluh diantaranya dikelola oleh operator atau jasa pengelola internasional. Salah satunya adalah hotel Grand Aston dan Fave Hotel di Yogyakarta yang merupakan hotel dengan kepemilikan lokal. Grand Aston dan Fave Hotel adalah hotel yang kepemilikannya baik properti maupun sahamnya secara penuh dimiliki oleh investor dalam negeri, namun kedua hotel ini dikelola dengan menggunakan jasa pengelola dari luar negeri yaitu Aston Internasional. Sedangkan sisanya dikelola oleh operator dalam negeri.

\section{B. Implikasi Kebijakan}

Dengan banyaknya jasa pengelola hotel internasional yang beroperasi di Indonesia khususnya di Yogyakarta, yang menjadi perhatian penting adalah bagaimana kebijakan pemerintah yang sudah ada mengatur tentang fenomena ini. Kemudian, bagaimana kebijakan tersebut berpengaruh kepada pelaku usaha jasa parisawata perhotelan dalam negeri. Meskipun sudah ada regulasi mengenai jasa pengelolaan hotel oleh operator internasional yang diatur dalam Keputusan Direktorat Jenderal (Dirjen) Pariwisata No:Kep.06/VI/97, namun didalam peraturan tersebut tidak ditemukan point yang mengatur tentang pembatasan komposisi atau presentase jumlah operator (jasa pengelola) asing yang beroperasi di dalam negeri. Kemudian, berdasarkan informasi yang telah kami dapatkan dari Ketua PHRI daerah Yogyakarta dan Dinas Pariwisata Kota Yogyakarta, tidak ada peraturan yang membatasi jumlah atau komposisi jasa pengelola hotel di Yogyakarta dari tingkatan berbintang sampai ke melati sekalipun. Menurut kami, hal ini akan menyulitkan bagi para pelaku industri perhotelan lokal terutama pelaku industri kecil dan menengah dimana mereka kebanyakan berada pada segemen hotel bintang dua kebawah. Para pelaku usaha jasa penginapan perhotelan lokal terutama pengusaha kecil dan menengah biasanya mengelola hotelnya dengan kemampuan manajerial moderate dan kebanyakan dikelola sendiri, berbeda dengan hotel-hotel yang menggunakan jasa pengelola hotel dari luar yang telah memiliki kemampuan manajemen yang tinggi dan sesuai dengan standar internasional. Sehingga apabila pengusaha kecil dan menengah dihadapkan dengan persaingan dari operator jasa pengelola hotel dari luar maka pegusaha lokal akan kalah bersaing dan hal ini akan mematikan pengusaha lokal, kecil dan menengah tersebut.

Pemerintah pusat sendiri memiliki ketentuan yang bertujuan untuk melindungi para pelaku industri kecil dan menengah dalam negeri dari persaingan langsung terhadap kompetitor luar yang lebih besar. Ketentuan ini tertuang dalam peraturan pemerintah pusat yang terdapat dalam UU No 10 tahun 2009 pasal 17 tentang kepariwisataan mengamanatkan perlindungan terhadap pelaku industri pariwisata kecil dan menengah. Meskipun pemerintah juga terikat dengan perjanjian kerjasama mengenai liberalisasi barang dan jasa dalam WTO melalui GATS, namun kepentingan para pelaku industri 
pariwisata lokal, kecil dan menengah juga harus diperhatikan oleh para pemangku kebijakan sesuai dengan yang diamanatkan oleh undang-undang.

Menurut pihak Dinas Pariwisata Kota Yogyakarta, pemerintah kota membuka seluas-luasnya investasi dari luar pada sektor pariwisata termasuk industri perhotelan. Argumen yang dikemukakan adalah dengan semakin banyaknya investasi baik dari luar negeri maka industri pariwisata akan tumbuh karena akan menimbulkan multiplier effect. Selain kontradiktif dengan PP No 36 tahun 2010 yang mengatur investasi asing maksimal 51 persen, asumsi tentang multiplier effect juga masih bisa diperdebatkan. Investasi asing di satu sisi tak dapat dipungkiri bahwa di dalam banyak kasus bisa mendatangkan keuntungan, namun disisi lain harus dipahami lebih dalam seberapa besar keuntungan yang didatangkan oleh investasi tersebut. Menurut wawancara kami dengan pihak Pusat Studi Pariwisata UGM, bahwa implikasi investasi perhotelan operator luar masih harus diteliti lebih mendalam bagaimana efeknya terhadap kemajuan industri pariwisata lokal, karena menurutnya kebanyakan operator asing telah mengatur para tamu kedalam paket-paket wisata yang semua rantai kegiatannya dikuasai oleh operator. Dari sini bisa dilihat bahwa multiplier effect yang diharapkan dapat merangsang pertumbuhan ekonomi masyarakat tidak terjadi, karena seluruh aktifitas rantai nilai produksi dalam industri pariwisata tersebut dikuasai oleh operator atau manajemen hotel.

Disamping itu, kontradiksi pernyataan pihak Dinas Pariwisata Kota Yogyakarta dengan PP No 36 tahun 2010, memperlihatkan lemahnya implementasi UU No 10 tahun 2009 tentang kepariwisataan Pasal 5: (f) Menjamin keterpaduan antarsektor, antardaerah, antara pusat dan daerah yang merupakan satu kesatuan sistemik dalam kerangka otonomi daerah, serta keterpaduan antarpemangku kepentingan. Kemudian, dari hasil interview dengan pihak Dinas Pariwisata Kota Yogyakarta, dinas terkait tidak memiliki mekanisme pengawasan dalam hal kerjasama sektor industri perhotelan atau pariwisata, padahal sektor ini penyumbang PAD terbesar untuk pemerintah Kota. Dinas hanya mengurusi masalah pembinaan pariwisata, jika ada keluhan dari pengusaha pariwisata khususnya perhotelan maka masalahnya akan diserahkan ke PHRI. Dapat diasumsikan bahwa peran PHRI dalam sektor jasa pariwisata khususnya perhotelan cukup penting, mengingat setiap keluhan dari pengusaha disampaikan kepada asosiasi ini.

Meskipun terdapat Undang-undang kepariwisataan yang mengamatkan tentang perlindungan terhadap pelaku industri pariwisata kecil dan menengah. Namun operasionalisasi UU tersebut ke dalam sebuah peraturan yang dapat melindungi pelaku industri lokal tidak ditemukan. Terutama di kota Yogyakarta, pemerintah daerah setempat tidak memiliki Perda yang merupakan implementasi dari UU No 10 tahun 2009 pasal 17 tentang perlindungan tersebut.

\section{Ekstrapolasi Kebijakan}

Kami melihat bahwa, PHRI sebagai perpanjangan tangan dan perwakilan dari pengusaha-pengusaha perhotelan tentunya mengerti regulasi 
atau kebijakan seperti apa yang dibutuhkan oleh pelaku industri pariwasata khususnya perhotelan untuk membantu proses usaha mereka terutama dalam menghadapi persaingan langsung dengan operator atau jasa pengelola hotel dari luar. Berdasarkan hasil wawancara kami dengan ketua PHRI Bapak KRHT. Drs. H. Istijdab M. Danunagoro, MM., bahwa pengusaha atau operator jasa pengelola hotel lokal tidak memerlukan peraturan untuk membatasi jumlah operator jasa pengelola hotel dari luar. Argumen yang beliau kemukakan adalah operator lokal telah mampu bersaing dan telah memiliki pasar sendiri-sendiri.

Jika melihat argumen ketua PHRI dapat dipahami memang operator lokal yang sudah "matang" mampu bersaing dengan operator asing, seperti Santika, Saphir, Jayakarta, mereka mungkin tidak teralalu mengalami kesulitan dalam menghadapi persaingan dengan Grand Aston dimana mereka telah memiliki pasar masing-masing. Akan tetapi, bagaimana dengan operator yang merupakan pengusaha kecil dan menengah sedangkan Aston Internasional terus berekspansi bahkan masuk ke pasar segmen bawah dengan fave hotel dan neo hotel. Ekspansi yang dilakukan oleh Aston Internasional ke segmen hotel-hotel yang lebih kecil atau bintang dua kebawah tentu akan menyulitkan para pengusaha industri jasa perhotelan lokal, kecil dan menengah, karena pada segmen ini mereka bermain dan pada umumnya mereka mengelola sendiri usahanya yang artinya manajemennya masih belum mapan.

Menurut kami, pola atau bentuk kebijakan yang dapat diambil oleh pemerintah daerah kota Yogyakarta untuk melindungi para pelaku usaha perhotelan kecil dan menengah lokal adalah dengan membatasi ruang bagi operator asing atau jasa pengelola manajemen hotel dari luar. Hal ini dapat dilakukan dengan hanya memperbolehkan operator asing mengelola hotelhotel yang berada diluar segmen para pelaku usaha perhotelan lokal, kecil dan menegah. Operator asing hanya boleh mengelola hotel-hotel yang berstandar diatas bintang dua saja.

Liberalisasi ekonomi dalam hal perdagangan jasa terkait dengan industri pariwisata memang merupakan sebuah hal yang harus dihadapi, namun demikian pemerintah harus tetap mengakomodasi kepentingan pengusaha lokal dalam menghadapi persaingan dengan operator atau pengelola jasa manajemen perhotelan dari luar negeri. Untuk itu diperlukan peran dan upaya yang serius dari pemerintah untuk dapat menerapkan kebijakan yang tepat dan dapat bermanfaat bagi kemajuan industri pariwisata lokal pada umumnya dan keberlangsungan hidup para pelaku industri pariwisata dan perhotelan lokal pada khususnya.

\section{Kesimpulan}

Adanya kontradiksi antara Peraturan yang ada di pusat dengan pemahaman aparatur di Daerah (Kota Yogyakarta) mengindikasikan kurangnya koordinasi dan sosialisai kebijakan yang ada di birokasi pemerintahan. Peran pemerintah dalam industri perhotelan dan pariwisata 
secara umum kurang, dimana pemerintah hanya mengandalkan pada investasi luar yang terbukti tidak dapat memberikan kemajuan yang signifikan bagi industri pariwisata di Indonesia dan terbukti bahwa industri pariwisata Indonesia kurang mampu bersaing dengan negara-negara lain di Asia Tenggara seperti Singapura, Malaysia, Thailand bahkan sekarang Vietnam. Seharusnya pemerintah lebih proaktif dalam mengurus industri pariwisata mengingat potensi Indonesia dan khususnya Yogyakarta sangat menjanjikan di bidang ini dengan keadaan alam dan kekayaan budaya yang sangat mendukung.

Indonesia memang terikat dalam perjanjian dengan WTO terkait dengan liberalisasi perdagangan jasa (pariwisata) di dalam mekanisme GATS, Namun beberapa celah dapat digunakan sebagai strategi untuk menghadapi liberaliasi perdagangan jasa tersebut:

- Ability, yakni kemampuan pemerintah dalam mendesain suatu kebijakan wajib didasarkan pada kemampuan riil yang dimiliki baik ditinjau dari dimensi internal maupun eksternal. Realitas kebijakan yang ada, kualitas sumber daya manusia, potensi produk yang ditawarkan, ketersediaan infrastruktur, penguasaan teknologi hingga konfigurasi persaingan global menjadi parameter untuk mengukur dan menganalisis kesiapan Indonesia dalam menghadapi fenomena kontemporer tersebut.

- National Interest menjadi faktor yang sangat penting dalam menentukan arah dan kendali liberalisasi pada subsektor-subsektor pariwisata. Tak hanya itu, kepentingan nasional mewajibkan pula pemerintah untuk mengutamakan dan memprioritaskan aspek manfaat bagi perekonomian dalam bentuk proteksi dan pengakomodasian kepentingan nasional dalam persetujuan GATS.

Gradual atau bertahap merupakan trademark GATS. Proses ini dapat diilustrasikan sebagai proses tebang pilih yang berorientasi pada kemampuan dan kepentingan sendiri sehingga tidak semua subsektor harus diliberalisasikan. Pemerintah mengambil peran penting dalam menentukan subsektor-subsektor apa yang sudah siap atau belum siap untuk diliberalisasi.).

\section{Daftar Pustaka}

Anonim. Hotel Aston, From Hawaii to Manado. Juli 23, 2008. http://www.hariankomentar.com/arsip/arsip_2008/jul_23/hl005.html (diakses 12 Desember, 2012).

Fadmawati, Kadek Dewi. Reformulasi Strategi Pemasaran Untuk Meningkatkan Occupancy Room Rate di Hotel Four Seasons Resort Jimbaran Bali. Denpasar: Tesis, Universitas Udayana, 2011.

Julian, I Nengah. Telaah Kontrak Manajemen Hotel Jaringan Internasional Antara Pihak Pemilik dan Pihak Pengelola Hotel Menurut Peraturan Kepariwisataan di Bali. Yogyakarta: Tesis Universitas Gadjah Mada, 2003.

Ksp, Robert Adhi. Charles Brookfield: Aston Bangun Hotel di Setiap Kota. 
Jl. KH. Ahmad Dahlan No.1, Pagesangan, Kec. Mataram, Kota Mataram, Nusa Tenggara

November

29 ,

2010.

http://properti.kompas.com/read/2010/11/29/09265483/Charles.Brookfield.As ton.Bangun.Hotel.di.Setiap.Kota (diakses 20 Oktober, 2012).

Nursyifani, Bunga Citra Arum. Jaringan Aston: Indonesia Bakal Punya 20 Hotel Neo. Oktober 5, 2012. http://www.bisnis.com/articles/jaringan-astonindonesia-bakal-punya-20-hotel-neo (diakses 20 Oktober, 2012).

Marchetti, Juan, and Petros Mavroidis. "The Genesis of the GATS." European Journal of International Law, June 2011: 689-721.

Putri, Prisca Prajatan. Strategi Promosi Divisi Public Relations Dalam Meningkatkan Ketertarikan Konsumen Atas Pelayanan Aston Rasuna Jakarta. Jakarta: Universitas Bina Nusantara, 2011.

Suyoto, Rahmat Slamet. Perkembangan Usaha Perhotelan Dalam Industri Pariwisata di Daerah Istimewa Yogyakarta. Yogyakarta: Tesis, Universitas Gadjah Mada, 2003.

Satoto, Agus. Pola Hubungan Penanaman Modal oleh Orang Asing Dalam Pembangunan Hotel di Bali. Yogyakarta: Tesis, Universitas Gadjah Mada, 2003. 